\title{
The Incidence of Low Back Pain among Healthcare Students and Their Beliefs on Its Association with Physical Function
}

\author{
GURBINDER KJS, ROSNITA H, NURUL SHAFINA MZ, NUR \\ ATHIRAH AHL, AHMAD FARHAN S, MOHD ZAIRIN Z \\ Department of Nursing, Faculty of Medicine, Universiti Kebangsaan Malaysia Medical \\ Centre, Jalan Yaacob Latif, Bandar Tun Razak, 56000 Cheras, Kuala Lumpur, Malaysia
}

\begin{abstract}
ABSTRAK
Kadar kekerapan sakit belakang yang lebih tinggi da;am kalangan profesional penjagaan kesihatan menyebabkan mereka kerap dimasukkan ke hospital, tidak hadir bekerja, dan bersara awal. Kepercayaan pemberi penjagaan kesihatan mengenai sakit belakang adalah penting dalam proses pemulihan pesakit yang menderita akibat sakit belakang. Kajian ini bertujuan untuk mengkaji insiden sakit belakang dalam kalangan pelajar prasiswazah kesihatan dan kepercayaan mereka terhadap perkaitan antara sakit belakang dan fungsi fizikal. Kajian keratan rentas digunakan untuk mengumpulkan data dalam talian dari pelajar prasiswazah kesihatan bagi semua tahun pengajian dari empat program. Alat soal-selidik "Extended Nordic Musculoskeletal Questionnaire" (NMQ-E) dan "Health Care Providers' Pain and Impact Relationship Scale" (HC-PAIRS) masingmasing digunakan untuk menentukan sakit belakang dalam kalangan pelajar dan kepercayaan mereka terhadap kesan sakit belakang pada fungsi fizikal. Seramai 239 pelajar mengambil bahagian dalam kajian ini dengan purata usia 21.90 tahun. Pelajar perempuan (74.5\%) melebihi lelaki (25.5\%). Ramai pelajar pernah mengalami sakit belakang sepanjang hayat hidup (82\%) dan 12 bulan terakhir (55.2\%) dengan permulaan pada awal usia remaja. Pelajar fisioterapi dan jurupulih carakerja mengalami sakit belakang pada kadar kekerapan yang lebih rendah pada bulan lepas dan hari pengumpulan data. Kadar kekerapan sakit belakang dalam kalangan pelajar lelaki dan perempuan adalah sama, tetapi lebih tinggi dalam kalangan pelajar tua berbanding pelajar muda. Pelajar jurupulih carakerja dan fisioterapi masing-masing didapati mempunyai kepercayaan yang lebih negatif dan positif terhadap sakit belakang. Kadar kekerapan sakit belakang yang lebih tinggi dalam kalangan pelajar pemberi penjagaan kesihatan memerlukan intervensi yang sesuai untuk mengatasinya. Kepercayaan positif yang sedikit dalam kalangan pelajar
\end{abstract}

Address for correspondence and reprint requests: Gurbinder Kaur Jit Singh. Department of Nursing, Faculty of Medicine, Universiti Kebangsaan Malaysia Medical Centre, Jalan Yaacob Latif, Bandar Tun Razak, 56000 Cheras, Kuala Lumpur, Malaysia. Tel: +603-91456259 Email: gurbin@ppukm.ukm.edu.my 
pemberi penjagaan kesihatan memerlukan tindakan segera untuk menanamkan kepercayaan positif dalam diri mereka.

\section{Kata kunci: kakitangan kesihatan, kekerapan, kuantitatif, pelajar, sakit belakang}

\section{ABSTRACT}

The high prevalence rate of low back pain (LBP) among healthcare professionals causes frequent hospitalisation, work absenteeism, and early retirement. Healthcare providers' beliefs about LBP are essential in the recovery process of patients suffering from LBP. This study was aimed to investigate the incidence of LBP among healthcare students and their beliefs on the association between LBP and physical function. A cross-sectional study was used to collect online data from all years undergraduate healthcare students of four programmes. The Extended Nordic Musculoskeletal Questionnaire (NMQ-E) and Health Care Providers' Pain and Impact Relationship Scale (HC-PAIRS) tools were used to determine LBP among the students and their beliefs on the impact of LBP on physical function, respectively. A total of 239 students participated in the study with a mean age of 21.90 years. Females (74.5\%) outnumber the males (25.5\%). Many students experienced LBP for a lifetime (82\%) and last 12 months (55.2\%) with initial onset at mid-teen-age. The physiotherapy and occupational therapy students experienced lower LBP during the last month and the day of data collection. The prevalence rate of LBP among males and females was the same, but higher among the seniors than junior students. Occupational therapy and physiotherapy students were found to have more negative and positive beliefs on LBP, respectively. The higher prevalence rate of $\mathrm{LBP}$ among the healthcare students requires appropriate interventions. The marginal positive beliefs among the healthcare students needs immediate actions to instil positive beliefs in them.

Keywords: back pain, health personnel, prevalence, quantitative, students

\section{INTRODUCTION}

Low back pain (LBP) is a common health problem among the global population, irrespective of age groups (Kennedy et al. 2014; Hafeez et al. 2013). Health care personnel are the main sufferer of LBP with a prevalence rate of around $56-74 \%$ compared to other professional workers (Hafeez et al. 2013), and it is also the common cause of frequent hospitalisation among them (Karahan et al. 2009). Chronic LBP leads to disability which causes work absenteeism and early retirement (Igwesi-Chidobe et al. 2019; Becker et al. 2010). Chronic LBP not only disrupts productivity and reduces revenue to industrialised countries, but also impairs quality of life of the 
disabled person and becomes a financial burden to the family (Deckers et al. 2015; Becker et al. 2010).

Several studies reported LBP among the healthcare students of the nursing, medical and physiotherapy programmes at different time intervals (Vincent-Onabajo et al. 2016; Falavigna et al. 2011; Mitchell et al. 2009). Both nursing (79\%) and physiotherapy (45.5\%) students reported a significantly much higher incidence of LBP for a lifetime than during a 7-day interval (Vincent-Onabajo et al. 2016; Mitchell et al. 2009). The prevalence of LBP among the physiotherapy students was notably high for the different time intervals of the lifetime, the last 12 months, and the day of data collection when compared with the medical students (Falavigna et al. 2011).

One's belief on the functional abilities of patients with LBP is important in determining the development of chronic LBP disability as high levels of negative beliefs on the functional abilities of patients with LBP are known to be related to the presence of $L B P$ and disability related to LBP (Burnett et al. 2009). A person's beliefs are shaped by ones' culture, learning and experience of LBP (Burnett et al. 2009; Ferreira et al. 2004). Healthcare providers' beliefs on the functional abilities of patients with LBP are essential in the recovery process of patients suffering from LBP. The healthcare providers' belief on the functional abilities of patients with LBP will affect the choice of treatment, advice and recommendations for their patients with chronic LBP (Springer et al. 2018; Kennedy et al. 2014; Ryan et al. 2010; Latimer et al. 2004). Positive and negative beliefs on the functional abilities of patients with LBP will wield positive and negative outcomes on the recovery of patients with $\mathrm{LBP}$, respectively, as the healthcare personnel's belief on the functional abilities of patients with LBP can influence the beliefs on the functional abilities of their patients (Springer et al. 2018; Ryan et al. 2010). In comparison to the beliefs on the functional abilities of patients with LBP among the physical therapy students from different countries (Australia, Brazil, and Saudi Arabia), significant differences were noted in the students' beliefs on the functional abilities of patients with LBP (Alshami \& Albahrani 2015). The negative belief on the functional abilities of patients with LBP was apparent among the physical therapy students irrespective of nationalities; the Saudi Arabia students scored the highest points on the negative belief on the functional abilities of patients with LBP, followed by the Brazilian and then the Australian students (Alshami \& Albahrani 2015).

Healthcare students, irrespective of the year of study, have demonstrated a positive belief that the LBP does not cause impairment (disability and activity limitations) compared to nonhealthcare students (Morris et al. 2012). The first-year medical students were significantly $(p<0.01)$ found to have positive beliefs on the functional abilities of patients with LBP when compared to the first-year business students, and their positive belief on the functional abilities of patients with LBP improved significantly as they advanced to the final year of their 
course (Morris et al. 2012). Similarly, senior physiotherapy and medical students showed significant positive belief in the functional abilities of patients with LBP than junior students of the same course (Springer et al. 2018; Kennedy et al. 2014).

Few studies reported no significant differences in students' beliefs on the functional abilities of patients with LBP across gender (Alshami \& Albahrani 2015; Morris et al. 2012; Ryan et al. 2010). However, according to Kennedy et al. (2014), female healthcare students of all disciplines (physiotherapy, medical, and nursing) reported having more negative beliefs on the functional abilities of patients with LBP when compared with the male students.

There are significant disparities in the students' beliefs on the functional abilities of patients with LBP among the various healthcare programme. The physiotherapy students were reported to show more positive beliefs followed by the chiropractic and medical students, while the pharmacy students show the least positive belief in a study by Briggs et al. (2013). Comparably, a significantly higher score $(p<0.05)$ on positive beliefs regarding the functional abilities of patients with LBP was observed among physiotherapy students compared to medical and nursing students (Kennedy et al. 2014).

As beliefs are likely to support practice behaviours of future healthcare professionals. Therefore this study was aimed to; firstly, determine the prevalence of LBP among the undergraduate healthcare students; secondly, explore the undergraduate healthcare students' belief on the functional abilities of patients with LBP; lastly, investigate the differences in students' belief on the functional abilities of patients with LBP among those with LBP and without LBP. In addition, cultural factor is noted to influence one's belief on the functional abilities of patients with LBP, with most studies involving healthcare students of western culture which are different from the Malaysian's culture. Therefore, the findings could have differed from the previous studies. Even though, the high prevalence rate of LBP among the healthcare students was reported in many studies, in one Malaysian study by Nor Azlin et al. (2014) among the undergraduate students of Universiti Kebangsaan Malaysia (UKM) was only investigating the incidence of LBP and factors associated with LBP among students from the Faculty of Health Sciences.

\section{MATERIALS AND METHODS}

\section{Study Design}

This was a cross-sectional quantitative study that allowed data collection at one point of time only among the same group of participants (LoBiondoWood \& Haber 2014). Fewer resources and limited time (2 months) of data collection involving many participants from the various programme in this study justified the use a cross-sectional design in this study.

\section{Study Setting, Population and Sample Size}

This study was conducted at the 
Faculty of Medicine and Faculty of Health Sciences of UKM in Malaysia. The selection of the faculties was based on the healthcare programmes offered. As the students from the healthcare programmes (nursing, medicine, physiotherapy, and occupational therapy) were involved in patients care upon graduation, the outcomes of this study helped in determining students' ability in providing appropriate care to patients with LBP.

All year undergraduate healthcare students of the four programmes (nursing, medicine, physiotherapy, and occupational therapy) who fulfilled the inclusion criteria of being able to understand the English language were selected as participants of this study $(\mathrm{N}=1,016)$. A sample of 307 (inclusive of $10 \%$ dropouts) based on Krejcie and Morgan's (1970) formula was considered appropriate for this study to ensure a good representative of each programme, the sample size for each programme of study was estimated as [nursing $(n=75)$, medical $(n=95)$, physiotherapy $(n=62)$, and occupational therapy $(n=75)]$. Since the number of students representing the physiotherapy and occupational therapy programmes was small, therefore all the students (100\%) from these programmes were recruited to participate in this study. On the other hand, 75 nursing students (55\% representation of the total nursing student population) and 95 medical students $(13 \%$ of the total medical student population) were recruited in this study.

\section{Instruments Used in this Study}

LBP among the students was measured using a valid and reliable Extended Nordic Musculoskeletal Questionnaire (NMQ-E) developed by Dawson et al. (2009) through modification of the original NMQ tool developed by Kuorinka et al. (1987). The 11 items NMQ-E measured the onset, prevalence and consequences of pain regarding nine body regions. However, in this study the focus was low back body region only. The 10 dichotomous items: "Yes" indicates had experienced pain, while a "No" indicates had not experienced pain with one item requesting time of initial onset of LBP. Permission to use the NMQ-E questionnaire was obtained from the developer.

Students' beliefs on LBP were measured using the modified Health Care Providers' Pain and Impact Relationship Scale (HC-PAIRS) developed by Evans et al. (2005). The original four-factor beliefs HC-PAIRS instrument by Rainville et al. (1995) was modified by Houben et al. (2004) to a single factor belief instrument. A minor modification by Evans et al. (2005) involved changing the word 'chronic back pain' to 'LBP'. Permission to use the HC-PAIRS questionnaires was obtained from the developer.

In this study, the instruments were tested for their internal consistency reliability with the studied participants. The Cronbach's alpha values were low $(\alpha=0.694)$ for HC-PAIRS and acceptable $(\alpha=0.748)$ for NMQ-E. Even though the HC-PAIRS has been widely used in many studies involving healthcare students (physiotherapy, medical, physical therapy, chiropractic, 
occupational therapy, pharmacy) (Latimer et al. 2004; Ferreira et al. 2004; Morris et al. 2012; Briggs et al. 2013; Alshami \& Albahrani 2015), the Cronbach alpha for HC-PAIRS was not reported in their studies. However, Springer et al. (2018) reported a low Cronbach alpha of 0.657 for the HC-PAIRS in their study among 85 physiotherapy students.

\section{Data Collection Method}

A pilot study was conducted after obtaining ethical approval, involving 28 nursing students $(10 \%)$ from the total sample size, as recommended by Connelly (2008). The participants involved in the pilot study were excluded from the actual study.

Data were collected from July to August 2020 after obtaining approval from the Research Ethics Committee of UKM Medical Centre (FF-2020114) and permission from the Deans of Faculty of Medicine and Faculty of Health Sciences of UKM. An online questionnaire booklet that consisted of three parts i.e.; Part A: socio-demographic data; Part B: LBP assessment; Part C: belief on LBP assessment was used to collect data. An online data collection method allowed students to complete the survey at their convenience.

The questionnaire was presented in the English language as the participants being university students were proficient in the English language. The questionnaire was accompanied by an information sheet outlining the purpose of the survey, requesting voluntary participation and instructions on how to complete the survey. The questionnaire was distributed to the students using Google Forms. The researchers made it clear to the students that they are under no obligation to complete the questionnaire. Only students who agreed to participate by submitting an online completed consent form beforehand could assess the questionnaire.

\section{Analysis of Data}

Data were analysed using the IBM SPSS version 26 (IBM Corp., Armonk, NY, USA). The descriptive statistics, mean and standard deviation were used to analyse the continuous variables (age and student's beliefs) while frequency distributions and percentages were used to calculate the categorical variables (incidence of LBP, gender, programme of study, year of study). Inferential statistics were used to examine the differences in belief on the functional abilities of patients with LBP among the students of various programmes of study as well as among students with and without LBP. A significant level was set at $p<0.05$.

The analysis was conducted after ensuring no missing values, errors, and out of range dataforeach of thevariables. The normality of the distribution of the total scores of beliefs about LBP was assessed using KolmogorovSmirnov and Shapiro-Wilk normality tests and was not normally distributed with significant KolmogorovSmirnov (difference $=0.059 ; p=0.045$ ) and non-significant Shapiro-Wilk (difference $=0.995 ; p=0.690$ ).

The electronic data was protected 
with a password to ensure the data were not exposed and its privacy was respected. The consent form, raw data, and any of coded data produced during analysis were stored in a CD and kept locked in a cupboard according to the institution's policy.

\section{RESULTS}

\section{Socio-demographic Data}

A total of 239 participants (response rate of $85.66 \%$ ) were involved in this study. A response rate of $81 \%$ was considered good (Badger \& Werrett 2005). The mean age of the participants was 21.90 years with the majority being females with a small representative of male students. The undergraduate healthcare students in this study included; medical $(n=86)$, nursing ( $n=61)$, occupational therapy $(n=53)$ and physiotherapy $(n=39)$. The majority of the students were in year $2(29.7 \%)$, followed by in descending order, years 1 and 3 (28.0\%), respectively, year $4(10.0 \%)$, with least were from year 5 (4.2\%) (Table 1$)$.

\section{Incidence of LBP among Undergraduate Healthcare Students}

The majority of the students $(82 \%)$, irrespective of programmes of study, stated experiencing LBP in a lifetime with their LBP initially starting much earlier at a mean age of 15.93 years. However, many of them (98.3\%) did not require hospitalisation. Even though LBP was apparent among the majority of the students (55.2\%) during the last 12 months, only a small number of them were unable to perform their normal work at home or away from home $(13.8 \%)$, have to consult a professional (doctor, physiotherapist, chiropractor) $(7.9 \%)$, have to consume medications because of LBP (8.4\%) and have taken sick leave from work/ study because of LBP (1.7\%) during that period, as shown in Table 2. More

Table 1: Socio-demographic data of participants

\begin{tabular}{|c|c|c|c|}
\hline & \multirow{2}{*}{ Variables } & \multicolumn{2}{|c|}{$N=239$} \\
\hline & & Mean $(+\mathrm{SD})$ & n (\%) \\
\hline Age & & $21.90( \pm 1.94)$ & \\
\hline \multirow[t]{2}{*}{ Gender } & Male & & $61(25.5)$ \\
\hline & Female & & 178 (74.5) \\
\hline \multirow[t]{4}{*}{ Programme of study } & Nursing & & $61(25.5)$ \\
\hline & Medicine & & $86(36.0)$ \\
\hline & Physiotherapy & & $39(16.3)$ \\
\hline & Occupational therapy & & $53(22.2)$ \\
\hline \multirow[t]{5}{*}{ Year of study } & Year 1 & & $67(28.0)$ \\
\hline & Year 2 & & $71(29.7)$ \\
\hline & Year 3 & & $67(28.0)$ \\
\hline & Year 4 & & $24(10.0)$ \\
\hline & Year 5 & & $10(4.2)$ \\
\hline
\end{tabular}


Table 2: Low back pain and effect of low back pain $(\mathrm{N}=239)$

\begin{tabular}{|c|c|c|c|}
\hline \multirow{2}{*}{ Variable } & \multicolumn{2}{|c|}{ n (\%) } & \multirow[t]{2}{*}{ Mean $(+\mathrm{SD})$} \\
\hline & Yes & No & \\
\hline Ever had LBP & $196(82.0)$ & $43(18.0)$ & \\
\hline Age during initial onset of LBP & & & $15.93( \pm 7.80)$ \\
\hline Ever hospitalised due to LBP & $4(1.7)$ & $235(98.3)$ & \\
\hline \multicolumn{4}{|l|}{ Ever during the last 12 months of LBP } \\
\hline $\begin{array}{l}\text { Prevent from doing routine work } \\
\text { Seek treatment from the professionals } \\
\text { Take medications } \\
\text { Take sick leave from work or study }\end{array}$ & $\begin{array}{c}33(13.8) \\
19(7.9) \\
20(8.4) \\
4(1.7)\end{array}$ & $\begin{array}{l}206(86.2) \\
220(92.1) \\
219(91.6) \\
235(98.3)\end{array}$ & \\
\hline LBP: low back pain & & & \\
\hline
\end{tabular}

Table 3: Prevalence of low back pain among the students $(\mathrm{N}=239)$

\begin{tabular}{|c|c|c|c|c|c|c|c|c|}
\hline \multirow{3}{*}{ Variable } & \multicolumn{8}{|c|}{ n (\%) } \\
\hline & \multicolumn{2}{|c|}{$\begin{array}{l}\text { Prevalence of } \\
\text { LBP for lifetime }\end{array}$} & \multicolumn{2}{|c|}{$\begin{array}{l}\text { Prevalence of LBP } \\
\text { for last } 12 \text { months }\end{array}$} & \multicolumn{2}{|c|}{$\begin{array}{l}\text { Prevalence of LBP } \\
\text { for last one month }\end{array}$} & \multicolumn{2}{|c|}{$\begin{array}{c}\text { Prevalence of LBP during } \\
\text { data collection day }\end{array}$} \\
\hline & Yes & No & Yes & No & Yes & No & Yes & No \\
\hline \multicolumn{9}{|c|}{ Program of study } \\
\hline Nursing & $\begin{array}{c}51 \\
(83.6)\end{array}$ & $\begin{array}{c}10 \\
(16.4)\end{array}$ & $\begin{array}{c}34 \\
(55.7)\end{array}$ & $\begin{array}{c}27 \\
(44.3)\end{array}$ & $\begin{array}{c}25 \\
(41.0)\end{array}$ & $\begin{array}{c}36 \\
(59.0)\end{array}$ & $\begin{array}{c}13 \\
(21.3)\end{array}$ & $\begin{array}{c}48 \\
(78.7)\end{array}$ \\
\hline Medical & $\begin{array}{c}71 \\
(82.6)\end{array}$ & $\begin{array}{c}15 \\
(17.4)\end{array}$ & $\begin{array}{c}51 \\
(59.3)\end{array}$ & $\begin{array}{c}35 \\
(40.7)\end{array}$ & $\begin{array}{c}38 \\
(44.2)\end{array}$ & $\begin{array}{c}48 \\
(55.8)\end{array}$ & $\begin{array}{c}27 \\
(31.4)\end{array}$ & $\begin{array}{c}59 \\
(68.6)\end{array}$ \\
\hline Physiotherapy & $\begin{array}{c}31 \\
(79.5)\end{array}$ & $\begin{array}{c}8 \\
(20.5)\end{array}$ & $\begin{array}{c}18 \\
(46.2)\end{array}$ & $\begin{array}{c}21 \\
(53.8)\end{array}$ & $\begin{array}{c}13 \\
(33.3)\end{array}$ & $\begin{array}{c}26 \\
(66.7)\end{array}$ & $\begin{array}{c}4 \\
(10.3)\end{array}$ & $\begin{array}{c}35 \\
(89.7)\end{array}$ \\
\hline $\begin{array}{l}\text { Occupational } \\
\text { therapy }\end{array}$ & $\begin{array}{c}43 \\
(81.1)\end{array}$ & $\begin{array}{c}10 \\
(18.9)\end{array}$ & $\begin{array}{c}29 \\
(54.7)\end{array}$ & $\begin{array}{c}24 \\
(45.3)\end{array}$ & $\begin{array}{c}14 \\
(26.4)\end{array}$ & $\begin{array}{c}39 \\
(73.6)\end{array}$ & $\begin{array}{c}5 \\
(9.4)\end{array}$ & $\begin{array}{c}48 \\
(90.6)\end{array}$ \\
\hline$x^{2}$ (p-value) & \multicolumn{2}{|c|}{$0.319(0.956)$} & \multicolumn{2}{|c|}{$1.888(0.596)$} & \multicolumn{2}{|c|}{$5.013(0.171)$} & \multicolumn{2}{|c|}{$12.781(0.005)^{*}$} \\
\hline \multicolumn{9}{|l|}{ Gender } \\
\hline Male & $\begin{array}{c}50 \\
(82)\end{array}$ & $\begin{array}{c}11 \\
(18)\end{array}$ & $\begin{array}{c}32 \\
(52.5)\end{array}$ & $\begin{array}{c}29 \\
(47.5)\end{array}$ & $\begin{array}{c}27 \\
(44.3)\end{array}$ & $\begin{array}{c}34 \\
(55.7)\end{array}$ & $\begin{array}{c}12 \\
(19.7)\end{array}$ & $\begin{array}{c}49 \\
(80.3)\end{array}$ \\
\hline Female & $\begin{array}{l}146 \\
(82)\end{array}$ & $\begin{array}{c}32 \\
(18)\end{array}$ & $\begin{array}{c}100 \\
(56.2)\end{array}$ & $\begin{array}{c}78 \\
(43.8)\end{array}$ & $\begin{array}{c}63 \\
(35.4)\end{array}$ & $\begin{array}{c}115 \\
(64.6)\end{array}$ & $\begin{array}{c}37 \\
(20.8)\end{array}$ & $\begin{array}{c}141 \\
(79.2)\end{array}$ \\
\hline$x^{2}$ (p-value) & \multicolumn{2}{|c|}{$0.000(1.000)$} & \multicolumn{2}{|c|}{$0.126(0.722)$} & \multicolumn{2}{|c|}{$1.168(0.280)$} & \multicolumn{2}{|c|}{$0.000(0.998)$} \\
\hline \multicolumn{9}{|l|}{ Year of study } \\
\hline Year 1 & $\begin{array}{c}53 \\
(79.1)\end{array}$ & $\begin{array}{c}14 \\
(20.9)\end{array}$ & $\begin{array}{c}33 \\
(49.3)\end{array}$ & $\begin{array}{c}34 \\
(50.7)\end{array}$ & $\begin{array}{c}22 \\
(32.8)\end{array}$ & $\begin{array}{c}45 \\
(67.2)\end{array}$ & $\begin{array}{c}10 \\
(14.9)\end{array}$ & $\begin{array}{c}57 \\
(85.9)\end{array}$ \\
\hline Year 2 & $\begin{array}{c}57 \\
(80.3)\end{array}$ & $\begin{array}{c}14 \\
(19.7)\end{array}$ & $\begin{array}{c}42 \\
(59.2)\end{array}$ & $\begin{array}{c}29 \\
(40.8)\end{array}$ & $\begin{array}{c}33 \\
(46.5)\end{array}$ & $\begin{array}{c}38 \\
(53.5)\end{array}$ & $\begin{array}{c}19 \\
(26.8)\end{array}$ & $\begin{array}{c}52 \\
(73.2)\end{array}$ \\
\hline Year 3 & $\begin{array}{c}57 \\
(85.1)\end{array}$ & $\begin{array}{c}10 \\
(14.9)\end{array}$ & $\begin{array}{c}38 \\
(56.7)\end{array}$ & $\begin{array}{c}29 \\
(43.3)\end{array}$ & $\begin{array}{c}26 \\
(38.8)\end{array}$ & $\begin{array}{c}41 \\
(61.2)\end{array}$ & $\begin{array}{c}14 \\
(20.9)\end{array}$ & $\begin{array}{c}53 \\
(79.1)\end{array}$ \\
\hline Year 4 & $\begin{array}{c}29 \\
(85.3)\end{array}$ & $\begin{array}{c}5 \\
(14.7)\end{array}$ & $\begin{array}{c}19 \\
(55.9)\end{array}$ & $\begin{array}{c}15 \\
(44.1)\end{array}$ & $\begin{array}{c}9 \\
(26.5)\end{array}$ & $\begin{array}{c}25 \\
(73.5)\end{array}$ & $\begin{array}{c}6 \\
(17.6)\end{array}$ & $\begin{array}{c}28 \\
(82.4)\end{array}$ \\
\hline$x^{2}(p$-value $)$ & \multicolumn{2}{|c|}{$1.202(0.752)$} & \multicolumn{2}{|c|}{$1.476(0.688)$} & \multicolumn{2}{|c|}{4.867 (0.178) } & \multicolumn{2}{|c|}{$3.161(0.367)$} \\
\hline
\end{tabular}

LBP: low back pain; *Significant at $\leq 0.01$ 
than one-third (37.7\%) of the students indicated having LBP last month and even during the day of data collection, LBP was still apparent among one-fifth $(20.5 \%)$ of the students.

Even though LBP for either a lifetime or the last 12 months was more apparent among the nursing, medical and occupational therapy students compared to physiotherapy students, the differences were not significant. The non-significant prevalence rate of LBP for the last month was more notable among the nursing, medical, and physiotherapy students than the occupational therapy students. However, a significant difference in LBP ( $p \leq 0.01)$ was noted among the different programmes of students during the day of data collection; both the physiotherapy and occupational therapy students reported a much lower prevalence of LBP than the nursing and medical students (Table 3).

No significant differences in the prevalence rate of LBP at different intervals (lifetime, last 12 months, last month, and day of data collection) were noted among the male and female students of all the healthcare programmes (Table 3).

Although the prevalence rate of LBP for a lifetime among the senior year students (2, $3 \& 4$ ) of all programmes was higher (80.3-85.3\%) compare to year 1 students $(79.1 \%)$ but it was not significant. Similarly, the prevalence rate of LBP during the last 12 months among the senior year students $(2,3$ \& 4) of all programmes was higher (55.9$59.2 \%)$ compare to year 1 (49.3\%) students but not significant. Likewise, the non-significant higher prevalence rate of LBP on the day of data collection (17.6-26.8\%) was apparent among the senior students (year 2, $3 \&$ \& ) than year $1(14.9 \%)$ students. However, the non-significant prevalence of LBP for the last one-month was more evident among the senior year 4 students compared to the junior year 1,2, and 3 students of all programmes (Table 3 ).

\section{Undergraduate Healthcare Student's Beliefs on the Functional Abilities of Patients with LBP}

Even though no significant differences in the mean score of beliefs on the functional abilities of patients with LBP among the students of various programme of study were obtained, the occupational therapy students with a higher mean score of 60.62 were found to have a more negative belief compared to other programmes of study. Physiotherapy students obtained the lowest mean score (mean=57.46) for this parameter. Both the medical and nursing students' beliefs on the functional abilities of patients with LBP were similar as the difference in the mean scores between these two groups of students were small. The nursing students had high variability in their belief on the functional abilities of patients with LBP with the highest standard deviation ( $\mathrm{SD}=9.608)$ (Table 4).

Differences in Undergraduate Healthcare Students' Belief on the Functional Abilities of Patients with or without LBP

An independent sample t-test was 
Table 4: Students' beliefs on the functional abilities of patients with LBP

\begin{tabular}{lcc}
\hline Programme of Study & Mean $( \pm$ SD) & F (df) (p value) \\
\hline Nursing & $57.92( \pm 9.608)$ & \\
Medical & $57.86( \pm 8.515)$ & $F(3,239)=1.422$ \\
Physiotherapy & $57.46 \pm 8.444)$ & $(p=0.237)$ \\
Occupational therapy & $60.62( \pm 8.839)$ & \\
\hline
\end{tabular}

conducted to find the differences in belief on the functional abilities of patients with LBP among the undergraduate healthcare students of all programmes who either had or had not experienced LBP. The finding show non-statistical significant differences among the nursing students. Similarly, the differences in the students' beliefs on the functional abilities of patients with LBP were not significantly apparent among the medical, physiotherapy, and occupational therapy students (Table 5).

\section{DISCUSSION}

Collectively, the prevalence rates of LBP among the students from all healthcare programmes were much higher for both the lifetime and the last 12 months intervals while being lower for both the last month (four weeks) and during the day of data collection intervals. However, the differences in LBP at different intervals among the different programmes of students were not significant, except during the day of data collection.

A high prevalence rate of LBP in a lifetime interval among the various healthcare programme students was supported by Mitchell et al. (2009) and Anggiat et al. (2018) while being contrary to Chiwaridzo et al. (2018) and Vincent-Onabajo et al. (2016). A higher prevalence rate of LBP in lifetime among the nursing students (79\%) (Mitchell et al. 2009) and healthcare students (74.6\%) (Anggiat et al. 2018)

Table 5: Differences in students' beliefs on the functional abilities of patients with LBP among those with or with low back pain $(\mathrm{N}=239)$

\begin{tabular}{|c|c|c|c|c|}
\hline \multirow[t]{2}{*}{ Variable } & \multirow[t]{2}{*}{ LBP } & \multicolumn{3}{|c|}{ Total score on beliefs } \\
\hline & & $\mathrm{n}$ & Mean $(+\mathrm{SD})$ & $t$ (p-value) \\
\hline \multirow[t]{2}{*}{ Nursing } & Yes & 51 & $58.51(+9.411)$ & \multirow{2}{*}{$\begin{array}{c}1.088 \\
(p=0.281)\end{array}$} \\
\hline & No & 10 & $54.90(+10.546)$ & \\
\hline \multirow[t]{2}{*}{ Medical } & Yes & 71 & $57.90( \pm 8.464)$ & \multirow{2}{*}{$\begin{array}{c}0.096 \\
(p=0.923)\end{array}$} \\
\hline & No & 15 & $57.67( \pm 9.053)$ & \\
\hline \multirow[t]{2}{*}{ Physiotherapy } & Yes & 31 & $57.58(+8.774)$ & \multirow{2}{*}{$\begin{array}{c}0.171 \\
(p=0.865)\end{array}$} \\
\hline & No & 8 & $57.00(+7.540)$ & \\
\hline \multirow[t]{2}{*}{ Occupational therapy } & Yes & 43 & $61.02(+9.438)$ & \multirow{2}{*}{$\begin{array}{c}0.681 \\
(p=0.499)\end{array}$} \\
\hline & No & 10 & $58.90( \pm 5.626)$ & \\
\hline
\end{tabular}

LBP: low back pain 
was reported in past studies. However, slightly more (56.7\%) and less (45.5\%) than half of the physiotherapy students in both Chiwaridzo et al. (2018) and Vincent-Onabajo et al. (2016) studies reported experiencing LBP in their lifetime, respectively. Students in the present study started experiencing LBP during their mid-teen-age, whereas in Chiwaridzo et al. (2018) it was during their late teen age (mean=19.7 years). All studies used the NMQ-E questionnaire to measure the prevalence of LBP among the students.

The high prevalence rate of LBP during the last 12 months interval among students of all programmes in this study was not severe to hinder many of them from performing their usual work, seeking treatment, consuming medications, and taking sick leave. These findings were supported by Crawford et al. (2018) and Mitchell et al. (2009) who used the NMQ-E questionnaire to measure the prevalence of LBP among the students. The last 12-month prevalence rate of LBP among the nursing and occupational therapy students was high at $77.9 \%$ and $77 \%$, respectively (Crawford et al. 2018). The nursing students in Mitchell et al.'s (2009) study reported disruption of activity, seeking treatment and consuming medication due to LBP at a lower rate $(28.0 \%$ to $44.4 \%$ ) despite having a higher (71\%) prevalence rate of LBP for the last 12 months. However, these findings were not in-line with Hendi et al. (2019), whereby the percentage of students who had LBP during the last 12 months was lower (33.4\%), with nearly half of the students $(47.5 \%)$ complaining that LBP causes interference in their work. The not significant lower prevalence rate of LBP during the last 12 months among the physiotherapy students than nursing, medical and occupational therapy students in the present study were contrary to those by Sklempe Kokic et al. (2019) and Hendi et al. (2019) as physiotherapy students in their studies reported a high prevalence rate of LBP during the last 12 months at $61.2 \%$ and $60.6 \%$, respectively.

The prevalence of LBP during the last month and the day of data collection intervals in this study was still apparent among several students with both physiotherapy and occupational therapy students experiencing lower LBP compared to the nursing and medical students. However, the significance was only apparent among the different programmes of students concerning the prevalence of LBP during the day of data collection. These findings were consistent with Vincent-Onabajo et al. (2016), partially consistent with Hafeez et al. (2013), and not consistent with Crawford et al. (2018). A small number of physiotherapy (17.7\%) (VincentOnabajo et al. 2016) and both the medical and nursing (21\%) (Hafeez et al. 2013) students reported to suffer from LBP during the last one-month. However, Crawford et al. (2018) reported a higher four-week prevalence rate $(61 \%)$ among health profession students. Hafeez et al. (2013) also found low (13.1\%) prevalence rates of LBP during the day of data collection among both the medical and nursing students. 
The possible reason for both the nursing and medical students to have a higher prevalence of LBP for all the intervals, especially for the last month and the day of data collection intervals could be due to higher incidence of LBP in association to a feeling of exhaustion, as reported in Alshayhan and Saadeddin (2018). The eight hours shift of clinical training (for a minimum duration of four weeks per semester) that is required for nursing students to provide nursing care to patients could cause them to feel exhausted at the end of their shift, leading to a higher incidence of LBP. As for the medical students, considering most of the participants in this study was from year 1 till year 3 and the majority of them were medical students, therefore, their clinical training which only commences in their third year of medical course could cause them to feel exhausted. The third year medical students were getting used to their busy schedule of having both the educational classes and clinical training on the same day, which lead them to have a higher incidence of LBP. The significant association between LBP and being in year 3 of the medical course as reported in Amelot et al.'s (2019) study further support the probable reason for the higher prevalence rate of LBP among medical students in the present study.

No significant difference in the prevalence of LBP among the gender of the students was found in the present study. However, male students suffered LBP at a greater rate $(77.8 \%)$ in Anggiat et al. (2018). Instead, while in Sklempe Kokic et al. (2019) reported a significantly higher prevalence rate of LBP among female students.

Although not significant, the senior year healthcare students of all programmes reported a slightly higher prevalence rate of LBP for the lifetime and during the last 12 months intervals than their junior students' in this study. These findings were supported by Arsh and Jan (2016) and not supported by Anggiat et al. (2018). The LBP in the lifetime and 12 months intervals was more prevalent among the final year medical and nursing students $(71.87 \%)$ than the year 1 students of the same programmes $(23.07 \%)$ (Arsh \& Jan 2016). Whereas, the year 1 healthcare students $(81.1 \%)$ reported higher LBP in the lifetime and 12 months intervals compared to years 2,3 , and 4 healthcare students (72.2-76.9\%) in Anggiat et al.'s (2018) study. The probable reason could be as noted in Nor Azlin et al.'s (2014) study of a significantly positive association between LBP and age. Older students above the age of 23 years who have enrolled in the undergraduate programmes for more than three years have a higher prevalence of LBP (Nor Azlin et al. 2014).

In the present study, occupational therapy and physiotherapy students were found to have more negative and positive beliefson thefunctional abilities of patients with LBP, respectively. These findings were in-line with Briggs et al. (2013), partially in-line with Springer et al. (2018), and contrary with Morris et al. (2012). Physiotherapy students in Briggs et al. (2013) study reported having a significantly positive beliefs on the functional abilities of 
patients with LBP than the medical and occupational therapy students. However, year 1 physiotherapy students reported higher positive belief in the functional abilities of patients with LBP than the year 2 and 4 students of the same course in Springer et al. (2018). Nevertheless, Morris et al. (2012) reported a positive belief in the functional abilities of patients with LBP among business studies students than medical students in their study. All studies used the HC-PAIRS questionnaire to measure the students' beliefs in the functional abilities of patients with LBP. The differing results among the studies could be due to a few factors i.e. the physiotherapy students in the present study were mostly senior students, similar to Briggs et al. (2013) and Springer et al. (2018) where the mean age of the participants in the former was 23.3 years while the latter mainly consisted of year 2 and 4 physiotherapy students. Similar to the participants in the present study, Brigg et al (2013) consisted of students who were knowledgeable and trained in pain management, allowing them to possess a higher belief with regards to the functional ability of LBP patients. The similarity was also evident among Springer et al. (2018) senior physiotherapy students, who were given a 26 -hour pain course to enable them to have a better understanding of the differences in the neurophysiology of pain in a normal and pathological condition. The business study students' positive belief on the functional abilities of patients with LBP in Morris et al. (2012) was reasonable as neither they have experienced working in uncomfortable postures for longer periods while providing care to patients during clinical posting nor need to take a pain course to understand the neurophysiology of pain in different conditions.

Even though the cultural factor is believed to influence a person's belief, the similarity in findings between the Malaysian healthcare students in the present study, and the Australian and Israeli healthcare students in Briggs et al. (2013) and Springer et al. (2018) studies, respectively, disproves the shows influence of culture in shaping a healthcare student's belief related to the functional abilities of patients with LBP.

In the present study, no statistical differences in belief on the functional abilities of patients with LBP among the undergraduate students with or without LBP, irrespective of programme of study. These findings were consistent with the findings of a few studies (Mukoka et al. 2019; Alshami et al. 2015; Burnett et al. 2009) that used the HC-PAIRS questionnaire. Past studies have shown no significant differences were noted in the mean score among the physiotherapy, nursing, (Burnett et al. 2009), and physical therapy (Alshami et al. 2015) students with and without a history of LBP. Likewise, no significant difference in beliefs on the functional abilities of patients with LBP ( $p=0.48)$ was found among the students of various healthcare programmes either with or without a previous history of LBP in Mukoka et al. (2019). Tan et al.'s (2014) findings among the healthcare personnel support the possible explanation of 
the similarity in the students' belief on the functional abilities of patients with or without LBP in this study. As despite healthcare personnel with LBP and high disability showing a negative belief on the functional abilities of patients with LBP when compared to those with LBP and low disability, the differences among them were not significant in their study.

The online data collection method used in the study hindered researchers from fulfilling the required sample size despite sending weekly reminders to the eligible participants. The unwillingness of the participants to complete an online survey is one of the disadvantages of using an online data collection method (Lefever et al. 2007). The use of convenience sampling in the study could not portray the significant differences in the students' beliefs on the functional abilities of patients with LBP among those with or without LBP.

\section{CONCLUSION}

The findings of a higher prevalence rate of LBP among the undergraduate healthcare students should be a cause for concern and addressed by the management of the institution. The initial onset of LBP at mid-teen-age requires further investigation, hopefully leading to implementation of preventive measures to tackle the continuation of LBP in adulthood. The undergraduate healthcare students' beliefs on the functional abilities of patients with LBP were marginally positive. Immediate measures are needed to instil positive beliefs in them as healthcare personnel beliefs on the functional abilities of patients with LBP can influence the beliefs of their patients. Further research with an equally proportionate undergraduate healthcare student with LBP and without LBP from all years could provide a more comprehensive outlook into the students beliefs on the functional abilities of patients with LBP. The identification of healthcare students' beliefs on the functional abilities of patients with LBP is crucial to determine the outcomes on the recovery of patients with LBP under their care during their professional career.

\section{ACKNOWLEDGEMENT}

The authors would like to acknowledge all the undergraduate healthcare students who participated in this study and the Deans of the Faculty of Medicine and Faculty of Health Sciences, UKM for their permission to have access to the students.

\section{REFERENCES}

Alshami, A.M., Albahrani, Y.A. 2015. A comparison of the attitudes toward chronic low back pain in Saudi, Australian and Brazilian physical therapy students. J Taibah Univ Med Sci 10(2): 181-7.

Alshayhan, F.A., Saadeddin, M. 2018. Prevalence of low back pain among health sciences students. Eur J Orthop Surg Traumato/ 28(2): 165-70.

Amelot, A., Mathon, B., Hadad, R. Renault, M.C., Duguet, A., Steichen, O. 2019. Low back pain among medical students: A burden and an impact to consider. Spine (Phila Pa 1976) 44(19): 1390-5.

Anggiat, L., Hon, W.H.C., Baait, S.N. 2018. The incidence of low back pain among university students. Jurnal Pro-Life 5(3): 677-87.

Arsh, A., Jan, A. 2016. Prevalence of low back pain among DPT students in Peshawar. South Asian Journal of Medicine 1(2): 29-34.

Badger, F., Werrett, J. 2005. Room for improvement? Reporting response rates and recruitment in nursing research in the past decade. J Adv Nurs 
51(5): 502-10.

Becker, A., Held, H., Redaelli, M., Strauch, K., Chenot, J.F., Leonhardt, C., Keller, S., Baum, E., Pfingsten, M., Hildebrandt, J., Basler, H.D., Kochen, M.M., Donner-Banzhoff, N. 2010. Low back pain in primary care: Costs of care and prediction of future health care utilization. Spine (Phila Pa 1976) 35(18): 1714-20.

Briggs, A.M., Slater, H., Smith, A.J., Parkin-Smith, G.F., Watkins, K., Chua, J. 2013. Low back painrelated beliefs and likely practice behaviours among final-year cross-discipline health students. Eur J Pain 17(5): 766-75.

Burnett, A., Sze, C.C., Ther, M.M., Tam, S.M., Yeung, K.M., Leong, M., Wang, W.T.J., Tan, B.K., O'Sullivan, P. 2009. A cross-cultural study of the back pain beliefs of female undergraduate healthcare students. Clin J Pain 25(1): 20-8.

Chiwaridzo, M., Chamarime, K.J., Dambi, J.M. 2018. The burden of low back pain among undergraduate physiotherapy students at the University of Zimbabwe: a cross-sectional study. BMC Res Notes 11(1): 697.

Connelly, L.M. 2008. Pilot studies. Medsurg Nursing 17(6): 411-2.

Crawford, R.J., Volken, T., Schaffert, R., Bucher, T. 2018. Higher low back and neck pain in final year Swiss health professions' students: worrying susceptibilities identified in a multicentre comparison to the national population. BMC Public Health 18(1): 1188.

Dawson, A.P., Steele, E.J., Hodges, P.W., Stewart, S. 2009. Development and test-retest reliability of an extended version of the nordic musculoskeletal questionnaire (NMQ-E): A Screening Instrument for Musculoskeletal Pain. J Pain 10(5): 517-26.

Deckers, K., De Smedt, K., Van Buyten, J.P., Smet, I., Eldabe, S., Gulve, A., Baranidharan, G., de Andres, J., Giligan, C., Jaax, K., Heemels, J.P., Crosby, P. 2015. Chronic low back pain: restoration of dynamic stability. Neuromodulation 18(6): 478-86.

Evans, D.W., Foster, N.E., Underwood, M., Vogel, S., Breen, A.C., Pincus, T. 2005. Testing the effectiveness of an innovative information package on practitioner reported behaviour and beliefs: The UK Chiropractors, Osteopaths and Musculoskeletal Physiotherapists Low back pain Management (complement) trial. BMC Musculoskeletal Disord 6: 1-16.

Falavigna, A., Teles, A.R., Mazzocchin, T., de Braga, G.L., Kleber, F.D., Barreto, F., Santin, J.T., Barazzetti, D., Lazzaretti, L., Steiner, B., Beckenkamp, N.L. 2011. Increased prevalence of low back pain among physiotherapy students compared to medical students. Eur Spine J 20(3): 500-5.

Ferreira, P.H., Ferreira, M.L., Latimer, J., Maher, C.G.,
Refshauge, K., Sakamoto, A., Garofalo, R. 2004. Attitudes and beliefs of Brazilian and Australian physiotherapy students towards chronic back pain: a cross-cultural comparison. Physiother Res Int 9(1): 13-23.

Hafeez, K., Ahmed Memon, A., Jawaid, M., Usman, S., Usman, S., Haroon, S. 2013. Back pain - are health care undergraduates at risk? Iran J Public Health 42(8): 819-25.

Hendi, O.M., Abdulaziz, A.A., Althaqafi, A.M., Hindi, A.M., Khan, S.A., Atalla, A.A. 2019. Prevalence of Musculoskeletal Disorders and its Correlation to Physical Activity Among Health Specialty Students. Int J Prev Med 10(48): 19-24.

Houben, R.M.A., Vlaeyen, J.W.S., Peters, M., Ostelo, R.W.J.G., Wolters, P.M.J.C., Stomp-Van Den Berg, S.G.M. 2004. Health Care Providers' Attitudes and Beliefs Towards Common Low Back Pain: Factor Structure and Psychometric Properties of the HC-PAIRS. Clin J Pain 20(1): 37-44.

Igwesi-Chidobe, C.N., Amarachukwu, C., Sorinola, I.O., Godfrey, E.L. 2019. Translation, cultural adaptation and psychometric testing of Igbo fear avoidance beliefs questionnaire in mixed rural and urban Nigerian populations with chronic low back pain. PLoS One 14(5): 1-22.

Karahan, A., Kav, S., Abbasoglu, A., Dogan, N. 2009. Low back pain: Prevalence and associated risk factors among hospital staff. J Adv Nurs 65(3): 516-24.

Kennedy, N., Healy, J., O'Sullivan, K. 2014. The beliefs of third-level healthcare students towards low-back pain. Pain Res Treat. 2014: 675915.

Krejcie, R.V., Morgan, D.W. 1970. Determining sample size for research activities. Educ Psychol Meas 30(3): 607-10.

Kuorinka, I., Jonsson, B., Kilbom, A., Vinterberg, H., Biering-Sørensen, F., Andersson, G., Jørgensen, K. 1987. Standardised Nordic questionnaires for the analysis of musculoskeletal symptoms. App Ergon 18(3): 233-7.

Latimer, J., Maher, C., Refshauge, K. 2004. The Attitudes and Beliefs of Physiotherapy Students to Chronic Back Pain. Clin J Pain 20(1): 45-50.

Lefever, S., Dal, M., Matthiasdottir, A. 2007. Online data collection in academic research: advantages and limitations. Br J Educ Technol 38(4): 574-82.

LoBiondo-Wood, G., Haber, J. 2014. Nursing research: Methods and critical appraisal for evidence-based practice. 8 ed. St. Louis: Mosby Elsevier.

Mitchell, T., O'Sullivan, P.B., Smith, A., Burnett, A.F., Straker, L., Thornton, J., Rudd, C.J. 2009. Biopsychosocial factors are associated with low back pain in female nursing students: A crosssectional study. Int J Nurs Stud 46(5): 678-88.

Morris, H., Ryan, C., Lauchlan, D., Field, M. 2012. Do 
medical student attitudes towards patients with chronic low back pain improve during training? a cross-sectional study. BMC Med Educ 12(1): 2-7.

Mukoka, G., Olivier, B., Ravat, S. 2019. Level of knowledge, attitudes and beliefs towards patients with chronic low back pain among final year school of Therapeutic Science students at the University of the Witwatersrand-A crosssectional study. S Afr J Physiother 75(1): 1-6.

Nor Azlin, M.N., Devinder, A.S., Lim, K. 2014. Low back pain and associated risk factors among health science undergraduates. Sains Malays 43(3): 423-8.

Rainville, J., Bagnall, D., Phalen, L. 1995. Health care providers' attitudes and beliefs about functional impairments and chronic back pain. Clin J Pain 11(4): 287-95.

Ryan, C., Murphy, D., Clark, M., Lee, A. 2010. The effect of a physiotherapy education compared with a non-healthcare education on the attitudes and beliefs of students towards functioning in individuals with back pain: An observational, cross-sectional study. Physiotherapy 96(2): 14450.

Sklempe Kokic, I., Znika, M., Brumnic, V. 2019. Physical activity, health-related quality of life and musculoskeletal pain among students of physiotherapy and social sciences in Eastern Croatia-Cross-sectional survey. Ann Agric Environ Med 26(1): 182-90.

Springer, S., Gleicher, H., Hababou, H. 2018. Attitudes and beliefs about musculoskeletal pain and its association with pain neuroscience knowledge among physiotherapy students in Israel. Isr J Health Policy Res 7(1): 67.

Tan, B.K., Smith, A.J., O'Sullivan, P.B., Chen, G., Burnett, A.F., Briggs, A.M. 2014. Low back pain beliefs are associated to age, location of work, education and pain-related disability in Chinese healthcare professionals working in China: a cross sectional survey. BMC Musculoskeletal Disord 15: 255.

Vincent-Onabajo, G.O., Nweze, E., Kachalla Gujba, F., Masta, M.A., Ali, M.U., Modu, A.A., Umeonwuka, C. 2016. Prevalence of low back pain among undergraduate physiotherapy students in nigeria. Pain Res Treat 2016: 1230384.

Received: 28 Sept 2020

Accepted: 19 Feb 2021 